\title{
Review on Air Cathode in Li-Air Batteries
}

\author{
Zhaoru Zha, Cai Shen, Deyu Wang and Wei-Qiang Han
}

\begin{abstract}
Ningbo Institute of Materials Technology \& Engineering, Chinese Academy of Sciences, Ningbo 315201, China
\end{abstract}

\begin{abstract}
Lithium-air (Li-air) battery is a promising electrochemical system with unprecedented high energy density. However, many problems and challenges prevent its wide scale application and commercialization. Low oxygen diffusion rates and large voltage gap are two of the main problems in Li-air battery. These two problems are related to the materials used in the air cathode such as porous carbon materials and metallic catalysts. This review seeks to discuss various materials used in the air cathode for $\mathrm{Li}$ air batteries. Mechanism of reaction in air cathode will be elucidated and discussed.
\end{abstract}

Keywords: Carbon material, porosity, capacity, catalyst, round-trip efficiency.

\section{INTRODUCTION}

Li-air (Li-air) battery was firstly developed in 1976. Nevertheless, it only started to gain popularity and recognition in the late 2000s with advances in materials technology and growing demand for non-fossil fuel energy sources [1]. Li-air batteries (Figure 1) generate energy through oxidation of lithium at the anode and reduction of oxygen at the cathode. Theoretically, it has 10-fold higher energy densities as compared to the current state-of-art lithium-ion batteries. Depending on the types of electrolytes, Li-air batteries can be divided into four categories: aprotic [2, 3], aqueous [4], solid state [5] and mixed aqueous/aprotic [6, 7]. Rapid development of Li-air battery in the past decade resulted in quite a number of sinificant publications on all aspects of Li-air battery, including anode [8], cathode [9, 10], electrolyte [11] and overall review [12].

The cathode of Li-air battery is the key in enhancing Li-air battery's performance. It consists of three components namely porous carbon material, binder and catalysts. It is where oxygen reduction reaction (ORR) takes place [13]. The mechanism of ORR is still poorly understood because of its complexity. However, there is a commonly accepted viewpoint [14] for aprotic Li-air cells which is now the prevailing category. Mechanism of ORR in aprotic Li-air battery is depicted in Figure 2. Firstly, oxygen molecule $\mathrm{O}_{2}$ undergoes a one-electron redox process ( $r_{1}$ in Figure 2) resulting in formation of superoxide anion radical $\left(\mathrm{O}_{2}{ }^{-}\right)$. In the presence of $\mathrm{Li}^{+}, \mathrm{LiO}_{2}$ is formed $\left(r_{3}\right.$ in Figure 2). This is followed by a disproportionation reaction to form lithium peroxide $\left(r_{4}\right.$ in Figure 2). In case of insufficient of

*Address correspondence to this author at the Ningbo Institute of Materials Technology \& Engineering, Chinese Academy of Sciences, Ningbo 315201 , China; Tel: +86-574-87615697; Fax: +86-574-87910728;

E-mail: hanweiqiang@nimte.ac.cn oxygen supply and abundant of $\mathrm{Li}^{+}$cation, lithium oxide $\left(r_{7}\right.$ in Figure 2) will be formed instead which severely affect the cyclability of Lithium air cells as lithium oxide is not easily decomposed even under very high potential. Thus, oxygen transport and discharge potential have great impact on energy generation and capacities [15]. Employing proper porous carbon materials and catalysts in the cathode will ensure proper oxygen transport, charged and discharged potential. This paper attempts to provide a comprehensive review on porous carbon materials and catalysts of the cathode of Li-air battery.

\section{POROUS CARBON MATERIAL}

Porous carbon material is an indispensable ingredient in the cathode of a Li-air battery. It is used as a substrate to load catalysts and discharge products. The specific surface area (SSA) of the porous carbon materials is the vital parameter to indicate its electrochemical performance. Porous carbon material with high SSA contains high amount of small pores which act as "highways" for air diffusion. However, a high SSA does not necessary lead to high specific capacity as smaller pores may not function properly [16]. In the following section, the commonly used carbon materials and criteria as a good carbon support will be reviewed.

\subsection{Commercial Porous Carbon Material}

Commercial porous carbon materials usually have high surface area $\left(1 \sim 3 \times 10^{3} \mathrm{~m}^{2} / \mathrm{g}\right)$ and demonstrate excellent performance when utilized in the cathode of Li-air battery.

M-30 is a porous carbon material produced by Osaka Gas Chemicals Co. Ltd. It has a very high SSA of 2500 to $3200 \mathrm{~m}^{2} \mathrm{~g}^{-1}$. When used as an active 

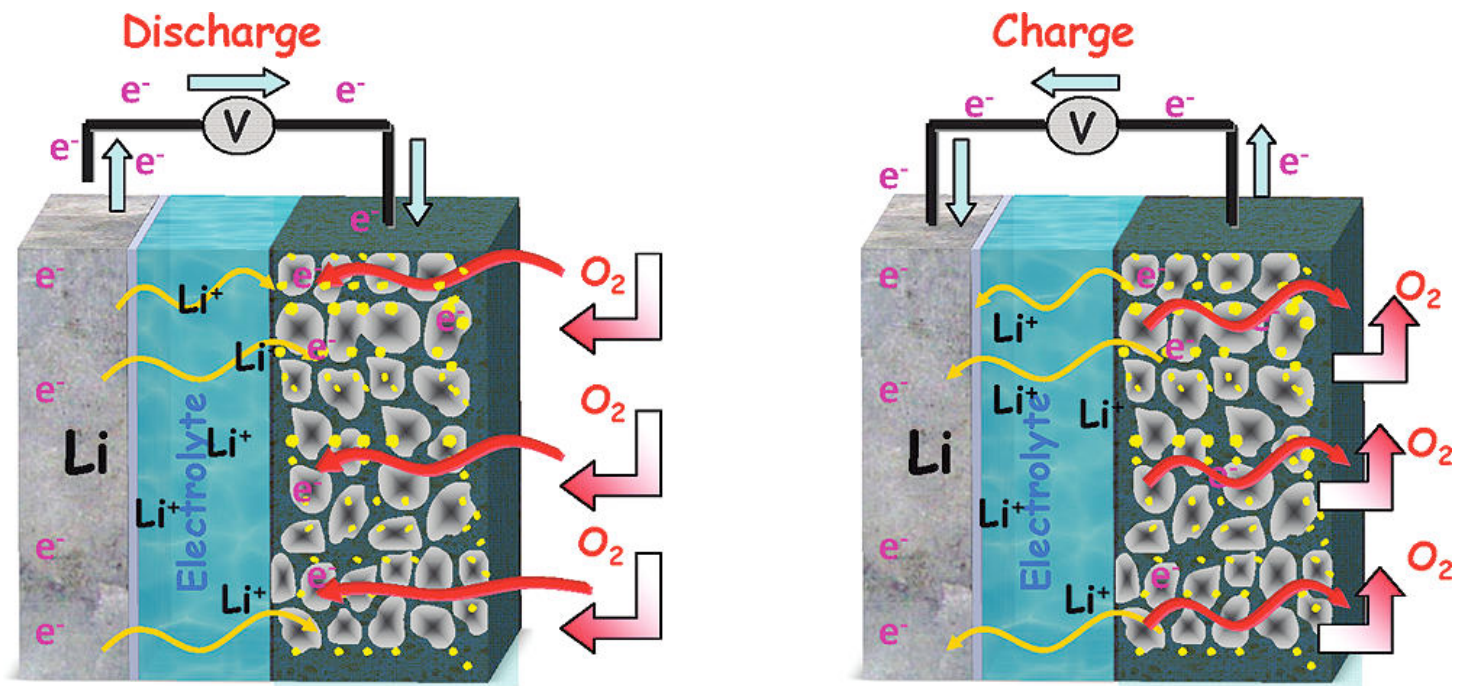

Figure 1: The charged and discharged process of Li-air batteries. Reprinted from ref. [1].

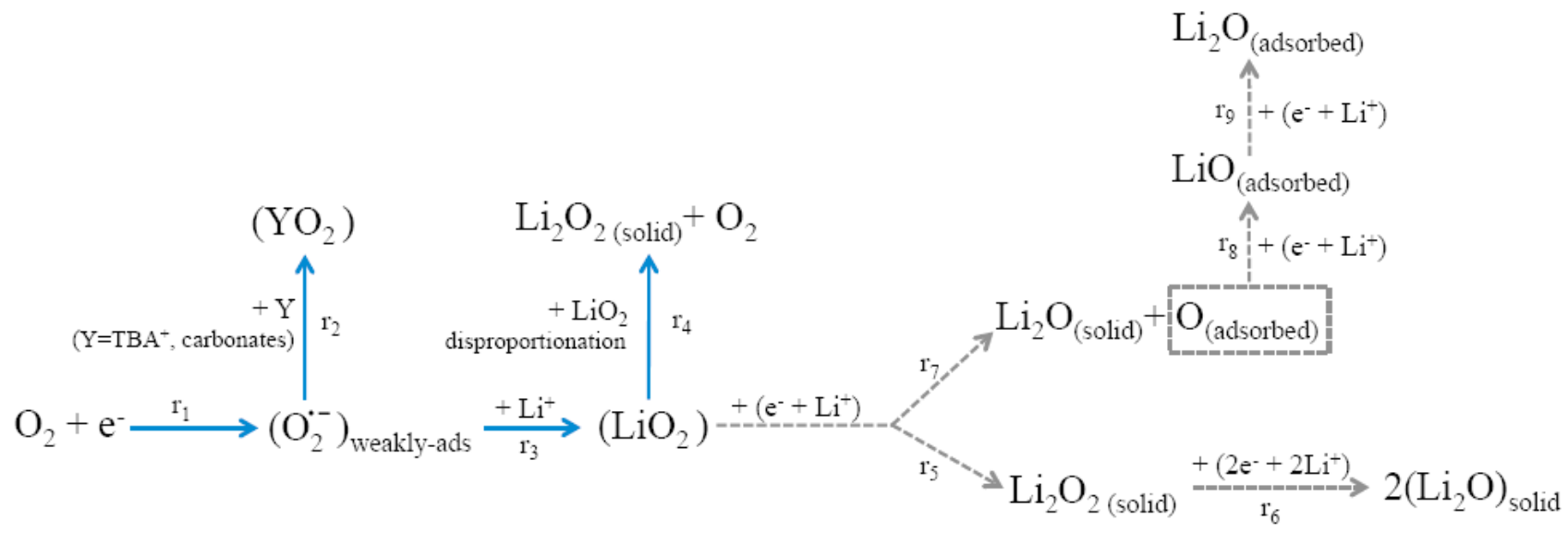

Figure 2: Reaction scheme of oxygen reduction reaction in aprotic media. Reprinted from Ref. [13].

material for air electrode without other catalysts, it produces a capacity of over $1500 \mathrm{mAh} / \mathrm{g}$ with a current density of $0.05 \mathrm{~mA} \mathrm{~cm}^{-2}$ in the presence of $0.2 \mathrm{M} \mathrm{Li}$-salt of $\mathrm{LiSO}_{3} \mathrm{CF}_{3}$ (dissolved in a 1:3 weight ratio mixture of propylene carbonate and 1, 2-dimethoxyethane). This is considerably lower than other carbon porous material with lower SSA [17]. A new air electrode model was established by Zheng et al. to explain this phenomenon. According to air-electrode model, the pores in carbon material are divided into three categories: micro-pores, macro-/meso- pores and interparticle pores (Figure 3 ). M-30 is mostly constituted by micro-size pores and macro-/meso- pores which can easily block oxygen diffusion when filled with liquid electrolyte. In addition, these two kinds of pores can also be easily blocked by precipitation of reaction products (such as $\mathrm{Li}_{2} \mathrm{O}_{2}$ ) $[9,18]$. Thus, it can be concluded that the majority of the specific capacity is contributed by inter-particle pores.

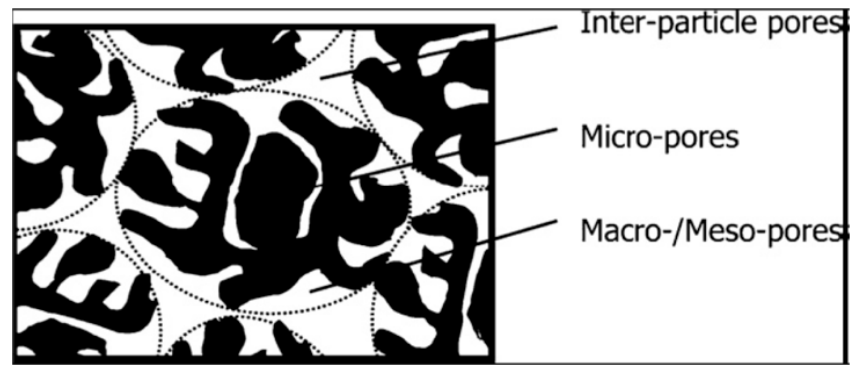

Figure 3: Types of pores in air cathode of Li-air batteries. Reprinted from ref. [16].

Super P; a product of Timcal, is a conductive carbon black widely used as additives in primary Zinccarbon and lithium batteries. Although its SSA is relatively low, its electrochemical performance is excellent. For instance, Freunberger et al. constructed a Li-air battery using Super P/Kynar as porous cathodes in an ether-based electrolytes which generated a capacity of ca. $3000 \mathrm{mAh} / \mathrm{g}$ at a current density of $70 \mathrm{~mA} / \mathrm{g}$ in the first cycle [19]. This is much 
higher than most kinds of amorphous carbon even those with have higher SSA. To demonstrate the impact of SSA on formation of discharge products, they replaced Super $P$ with two other carbons having higher surface area: Ketejen Black (Product of Akzonobel with a surface area of $1400 \mathrm{~m}^{2} / \mathrm{g}$ ), and Black Pearls 2000 (Product of Cabot with a surface area of $1369 \mathrm{~m}^{2} / \mathrm{g}$ ). They examined the discharged products by powder $\mathrm{x}$ ray diffraction (PXRD), Fourier transform infrared spectroscopy (FTIR), and nuclear magnetic resonance (NMR) spectroscopy; and found most of the reaction products are identical with only slight difference in ratios. However, polyethers and esters can only be found when Black Pearls are used as carbon substrate. The fact that two different kinds of carbon materials with similar specific surface area resulting in different discharge products indicates morphology of carbon materials is also a critical factor.

Ketejen Back (KB) EC600JD, a product of Akzonoble, also has an excellent electrochemical performance. A specific capacity of $5813 \mathrm{mAh} / \mathrm{g}$ under a current density of $0.1 \mathrm{~mA} / \mathrm{cm}^{2}$ can be reached without the use of catalysts [20]. The air cathode was prepared by mixing $\mathrm{KB}$ and polyvinylidene fluoride (PVDF) in a 40:60 ratio $(\mathrm{w} / \mathrm{w})$ and tested in an electrolyte of $0.9 \mathrm{M}$ $\mathrm{LiPF}_{6}$ in ethylene carbonate (EC): propylene carbonate (PC) 1:1 (w/w). They also found that increased carbon loading lead to decreased porosity of the electrode which resulted in a negative impact on specific capacity.

Commercial carbon black material doped with nitrogen can also be used to make air electrode. Nitrogen atoms provide additional electrons to the carbon lattice [21]. Thus, reducing the energy gap between the highest-occupied and lowest-unoccupied molecular orbitals. This facilitates electron transfer from carbon material to adsorbed oxygen species [22, 23]. Kichambare et al. found that the $\mathrm{N}$-doped carbon materials has $0.2 \mathrm{~V}$ higher discharge potential and almost doubled capacity than those of pristine carbon materials [24]. However, a research conducted by Li et al. shown that the discharge specific capacity is closely related to the specific surface area of mesopores and have little thing to do with the atoms doped [25].

\subsection{Carbon Nanotube/Nanofiber}

Carbon nanotubes (CNT) have high electronic conductivity and specific surface area, which make them suitable materials for air cathode. N-doped CNTs perform even better due to its improved electronic conductivity [26] and its catalytic role. Li et al. prepared an air cathode by mixing N-CNTs and PVDF in a ratio of $9: 1(\mathrm{w} / \mathrm{w})$ and demonstrated an initial discharge capacity of $866 \mathrm{mAh} / \mathrm{g}$ at a current density of $75 \mathrm{~mA} / \mathrm{g}$ which is about 1.5 times as much as that of CNTs (590 $\mathrm{mAh} / \mathrm{g}$ ) [27]. The N-CNTs electrode also showed an average discharge plateau of $2.51 \mathrm{~V}$, which is $0.1 \mathrm{~V}$ higher than that of pristine CNTs electrode. These results indicate electro-catalytic activity of N-CNTs facilitates the cathodic reactions during discharge [24].

CNT can also be modified to achieve high gravimetric capacities. Zhang et al. produced $\mathrm{CNT/carbon}$ nanofiber or buckypapers using a mixture of single-walled carbon nanotube (SWCNT) and carbon nanofiber (CNF) at the ratio of 1:3 (w/w) [28]. Entanglement of SWNTs and CNFs in the buckpapers ensured good mechanical property which prevents pulverization during charge-discharge cycles (Figure 4). For CNT buckypapers, thickness of the air electrode affects the discharge capacity. Thin air electrode with a thickness of $20 \mu \mathrm{m}$ generates a specific capacity of $2550 \mathrm{mAh} / \mathrm{g}$ at a discharge current density of 0.1 $\mathrm{mA} / \mathrm{cm}^{2}$. However, the capacity decreased rapidly to 1580 and $350 \mathrm{mAh} / \mathrm{g}$ when the thickness of the electrode was increased to 66 and $220 \mu \mathrm{m}$, respectively. This may indicate easier blockage of pores in thicker air cathode due to a longer pathway.

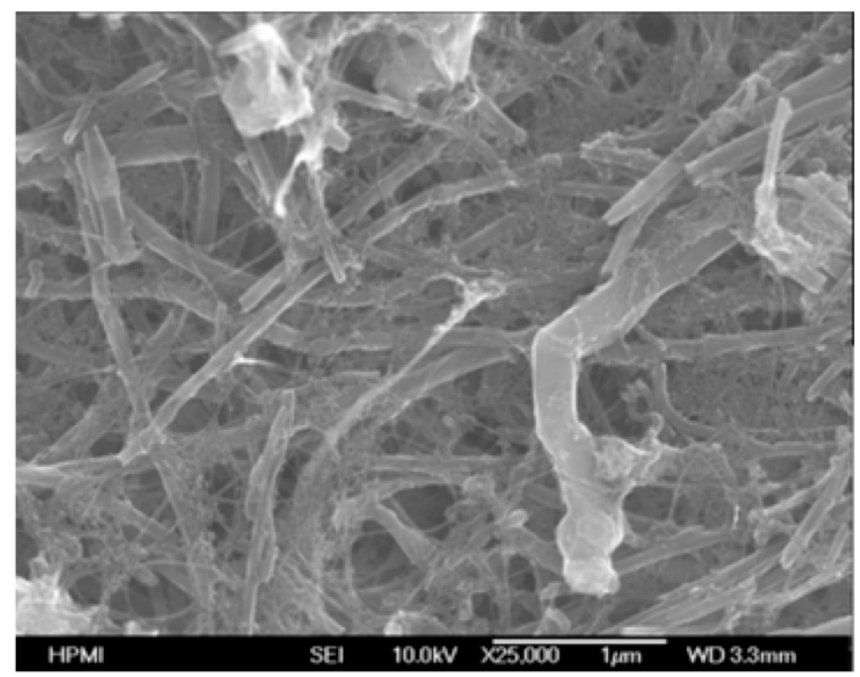

Figure 4: SEM image of a buckypaper surface. SWNTs and CNFs are entangled together to increase the strength of buckypaper. Reprinted from ref. [26].

Freestanding CNF electrodes can be fabricated by atmospheric pressure CVD method on porous anodized aluminium oxide (AAO) substrates coated with two thin layers of $\mathrm{Ta}(30 \mathrm{~nm}$ in thickness) and $\mathrm{Fe}$ (2 $\mathrm{nm}$ in thickness) (Figure 5) [29]. Due to the unique 

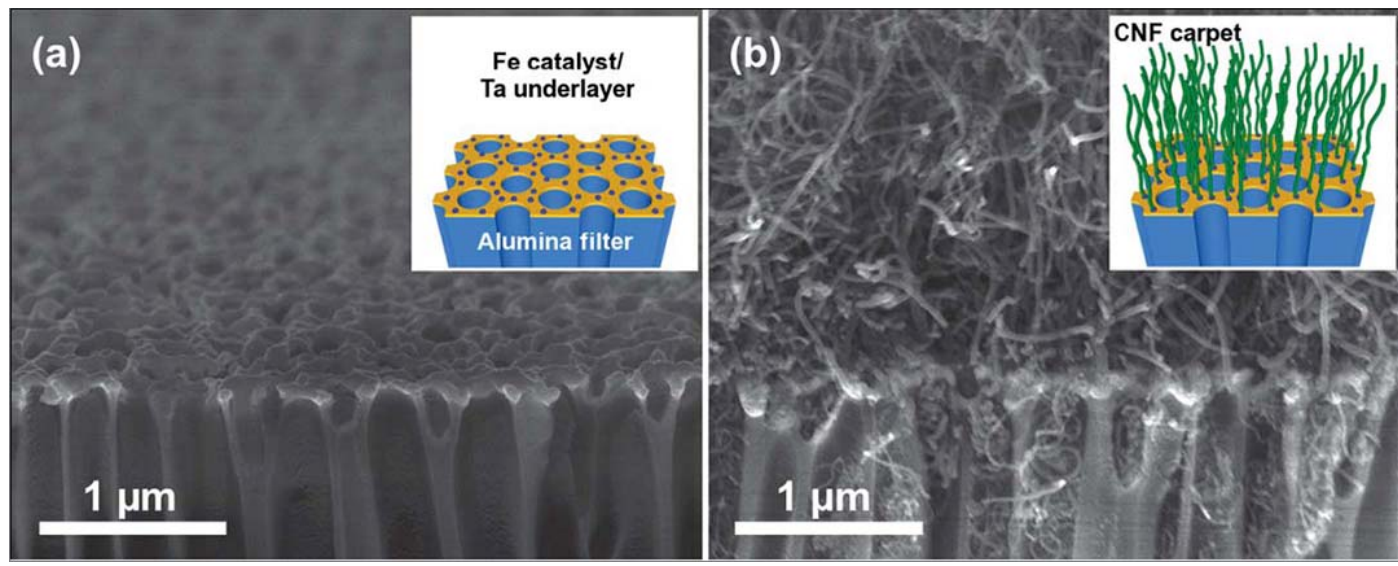

Figure 5: (a) Cross-sectional $\left(70^{\circ}\right.$-tilt) SEM micrograph of the porous anodized aluminium xide (AAO) filter Inset: schematic presentation of the electrode after deposition of metal thin films (Ta $30 \mathrm{~nm}, \mathrm{Fe} 2 \mathrm{~nm}$ ) onto one side of the AAO filter. (b) Crosssectional $\left(70^{\circ}\right.$-tilt) SEM image of the AAO filter after nanofibergrowth. Inset: schematic representation of the electrode after catalyzed growth of carbon nanofibers. Reprinted from ref. [27].

structure of this material, different structures of $\mathrm{Li}_{2} \mathrm{O}_{2}$ were formed during different depth of discharge. At the beginning of the discharge, discrete spherical particles with an average diameter of ca.100 nm were found on the CNF sidewalls. After that, toroidal-shaped particles with an average diameter of ca. $400 \mathrm{~nm}$ appeared. At the end of discharge, the discrete particles merged to form a monolithic $\mathrm{Li}_{2} \mathrm{O}_{2}$ mass which blocks oxygen transport. At a current density of $63 \mathrm{~mA} \mathrm{gc}^{-1}$, an outstanding discharge capacity of $7200 \mathrm{mAh} \mathrm{gc}^{-1}$ can be achieved.

\subsection{Mesocellular Carbon Foam}

Mesocelluar carbon foams (MCF-C) can also be implemented as air cathode [30]. MCF-C can be prepared by using sucrose as carbon source and mesocelluar foam silica (MCF) as removable template It has well-defined spherical cell pores with a uniform inner diameter of ca. $28 \mathrm{~nm}$ and outer diameter of ca.
$38 \mathrm{~nm}$ (Figure 6). These ultra-large mesopores are not easily blocked by liquid electrolyte and discharge products: thus, making it favorable for oxygen diffusion and subsequently superior specific capacity. In the electrolyte of $1 \mathrm{M} \mathrm{LiClO} /$ /propylene carbonate, MCF-C with a specific surface area of $824 \mathrm{~m}^{2} / \mathrm{g}$ can deliver a discharge capacity of $2500 \mathrm{mAh} / \mathrm{g}$ at a current density of $0.1 \mathrm{~mA} / \mathrm{cm}^{2}$, which is about $40 \%$ higher than that of Super $P$.

\subsection{Graphene}

Graphene is a two dimensional material consisting of a single layer of carbon atoms arranged in a honeycomb or chicken wire structure. It has high electrical conductivity and other outstanding electrical properties making it suitable for energy generation and storage [31]. Theoretically, single-layer graphene sheet has the highest specific surface area of $2630 \mathrm{~m}^{2} / \mathrm{g}$. However, graphene derived from microwave- and
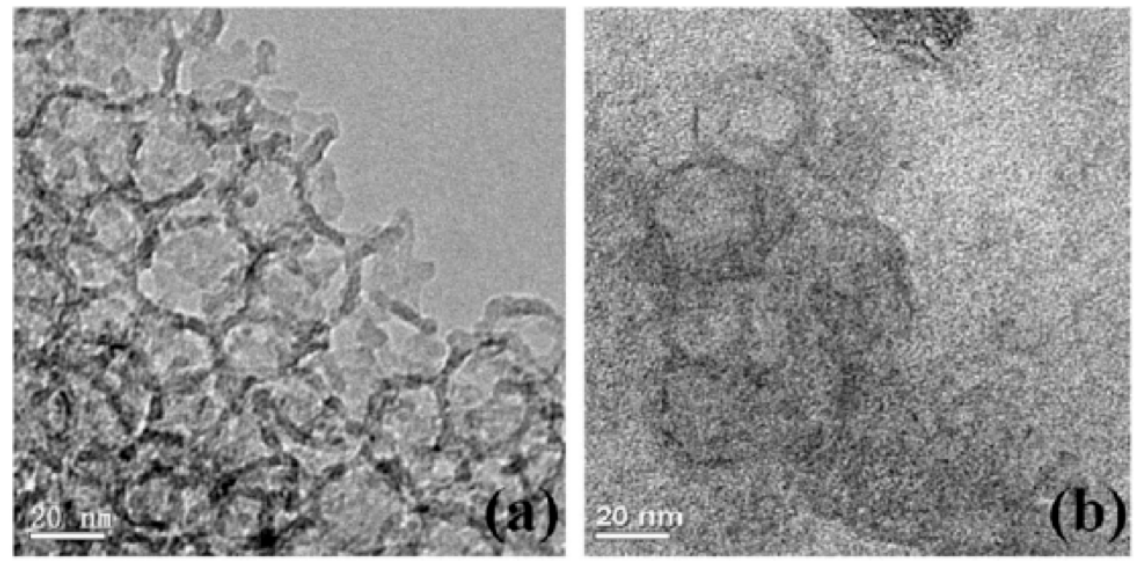

Figure 6: TEM image of (a) MCF-silica and (b) MCF-C. The structure of MCF-C is not exactly the same as that of its template (MCF-silica), but the framework was still maintained. Reprinted from ref. [28]. 
thermally-exfoliated graphene oxide can achieve a specific surface area up to $3100 \mathrm{~m}^{2} / \mathrm{g}$ due to $\mathrm{KOH}$ activation [32].

Graphene nanosheets (GNSs) can be used in production of air electrode [33]. They have lower voltage gaps, better cyclabilities and $30 \%$ higher specific capacities as compared to that of Vulcan XC72, a carbon black product of Cabot, which is often used as carbon substrate for air cathodes. These improvements might be attributed to presence of carbon vacancies and defects on the synthesized GNSs surface. GNSs can also be doped with nitrogen for better electrochemical performance [34]. N-doped GNSs has ca.0.2V higher ORR potential than pristine ones. Li et al. also demonstrated that the doping of nitrogen atoms can lead to a higher specific capacity [35].

To further improve its performance, Xiao et al. prepared a functionalized grapheme nanosheet (FGS) with ideal bimodal porous structure by thermal expansion method [18, 36]. The bimodal porous structure of FGSs contained large tunnels and small pores. During discharge, the robust large tunnels can function as "highways" to supply oxygen to the interior parts of air electrode. Meanwhile, the small pores on the walls provide triphase regions (solid-liquid-gas) required for oxygen reduction. These functionalized graphene nanosheets (FGSs) has a C/O ratio of $\sim 14$ and $\sim 100$. FGS with a $\mathrm{C} / \mathrm{O}$ ratio of $\sim 14$ (specific capacity of about $15000 \mathrm{mAh} / \mathrm{g}_{\text {carbon}}$ ) had a better performance than FGS with a C/O ratio of $\sim 100$ (specific capacity of about $9000 \mathrm{mAh} / \mathrm{g}_{\text {carbon }}$ ) in oxygen (2atm) (Figures 7a and 7d). FGS with higher $\mathrm{C} / \mathrm{O}$ ratio has less lattice defects and/or functional groups in grapheme resulting in lower electrochemical performance of the cell. In ambient environment, the specific capacity still exceeded $5000 \mathrm{mAh} / \mathrm{g}_{\text {carbon }}$ at the same current density (Figure 7c). Then they used DFT calculation to further confirm their discoveries. These calculations were performed by Vienna ab initio simulation package (VASP). The results demonstrated that the binding energy of $\mathrm{Li}_{2} \mathrm{O}_{2}(-0.26 \mathrm{eV})$ monomer become much stronger at the vicinity of 5-8-5 defect site $(-0.70 \mathrm{eV})$ and even stronger with a $-\mathrm{COOH}$ group associated $(-0.90 \mathrm{ev})$. This indicates that $\mathrm{Li}_{2} \mathrm{O}_{2}$ particles tended to nucleate and grow around defect sites. Another calculation showed that aggregation of $\left(\mathrm{Li}_{2} \mathrm{O}_{2}\right)_{n}$ clusters are energetically unfavorable and the clusters tended to be isolated rather than growing larger. The result is that the air tunnels will not be easily blocked, thus induce a higher specific capacity.

Free-standing graphene in nickel foam can be synthesized through in situ sol-gel method and can be
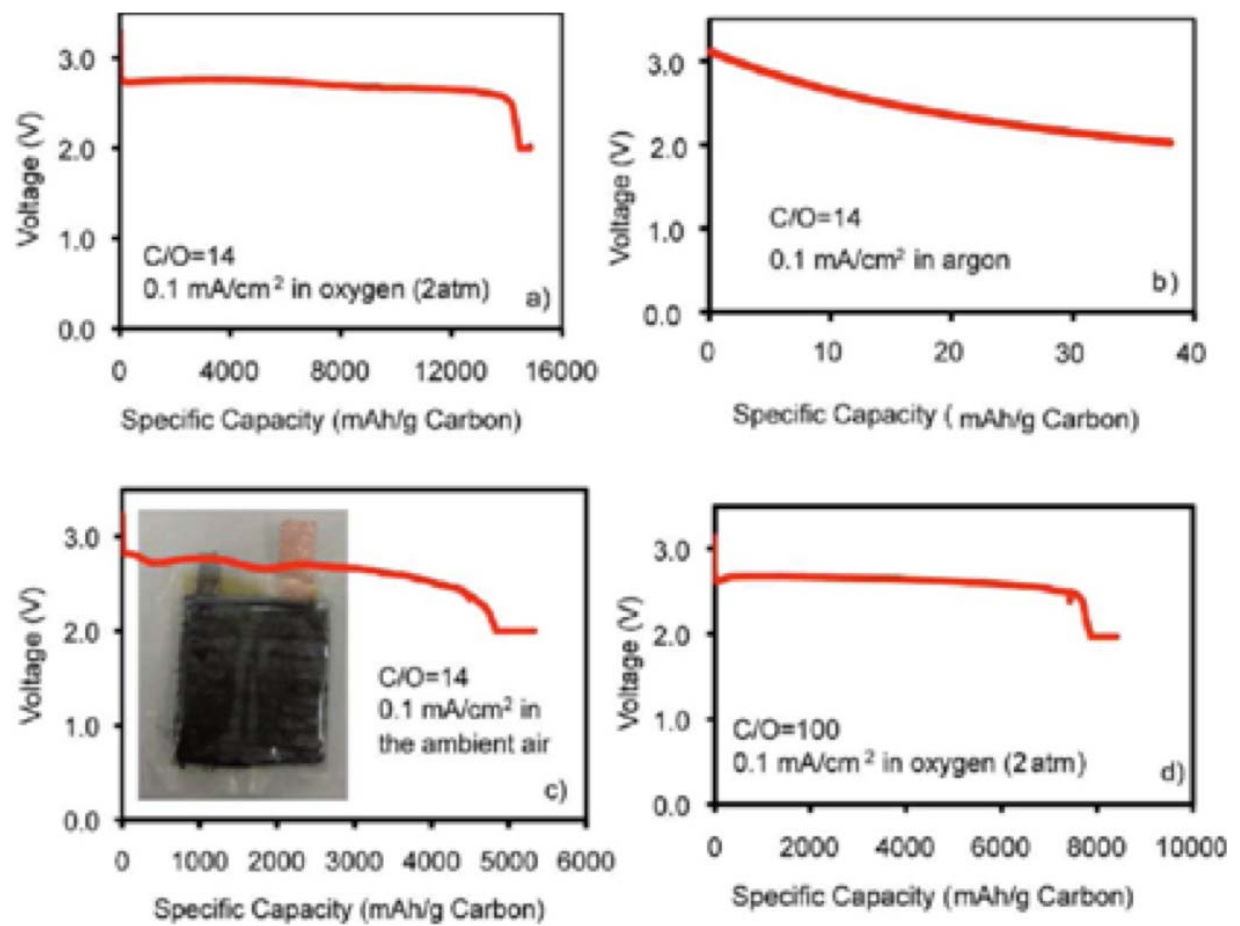

Figure 7: The discharge curve of different Li-air cells in different environment. (a) The discharge curve of a Li-air cell using FGS $(\mathrm{C} / \mathrm{O}=14)$ as the air electrode $\left(\mathrm{P}_{\mathrm{O} 2}=2 \mathrm{~atm}\right)$. (b) The same Li-air cell as in (a) tested in pure argon. (c) The discharge curves of pouch-type cell (as the inset shows) using the same FGS as mentioned above tested in the ambient air. (d) Discharge curve of Li-air cell using FGS $(\mathrm{C} / \mathrm{O}=100)$ as air cathode $\left(\mathrm{P}_{\mathrm{O} 2}=2 \mathrm{~atm}\right)$. Reprinted from ref. [17]. 
used as current collector without addition of binder [37, $38,39]$. Modified nickel foam was made from treating pristine nickel foam in a growth solution containing $\mathrm{Ni}$ salt. GO dispersion was then treated with organic solgel method and casted onto the nickel disks. Due to the weak acid, part of the nickel foam was etched and dissolved in the solution forming $\mathrm{NiOOH}$ which acts as a binder between the precursor gel and the nickel foam. The dry gel embedded in the nickel foam was carbonized in $\mathrm{N}_{2}$ forming free-standing hierarchically porous carbon (FHPC) electrodes which were used as cathodes for $\mathrm{Li}-\mathrm{O}_{2}$ batteries. This battery demonstrated a remarkable performance for the discharge capacity $\left(11060 \mathrm{mAhg}^{-1}\right)$ at a current density of $0.2 \mathrm{mAcm}^{-2}$ $\left(280 \mathrm{mAg}^{-1}\right)$.

In short, carbon materials can act as air diffusion tunnel. However, their catalytic activities are relatively weak. Carbon materials only are incapable of diminishing the voltage gap between oxygen evolution reaction (OER), the charge reaction of Li-air batteries, and oxygen reduction reaction (ORR), the discharge reaction of $\mathrm{Li}$-air batteries resulting in lower round-trip efficiency. Catalysts such as metallic catalysts can be used to reduce the voltage gap between OER and ORR.

\section{METALLIC CATALYSTS}

Metallic catalysts reduce the voltage gap between OER and ORR by lowering the voltage plateau of OER and alleviating that of ORR, which results in a high round-trip efficiency. Chemical properties and nanostructures of the catalysts have major impacts on the cell performance. In addition, it affects the reversibility of $\mathrm{Li}-\mathrm{O}_{2}$ battery by altering the discharge product ratio of $\mathrm{Li}_{2} \mathrm{O}_{2}$ and $\mathrm{Li}_{2} \mathrm{O}$. $\mathrm{Li}_{2} \mathrm{O}_{2}$ is a favorable discharge product for specific capacity. Meanwhile, $\mathrm{Li}_{2} \mathrm{O}$ is electrochemically inactive. Accumulation of $\mathrm{Li}_{2} \mathrm{O}$ causes the attenuation of the discharge capacity. Catalysts can also promote oxygen reduction reaction in the cathode by assisting the cleavage of di-oxygen bond and formation of $\mathrm{Li}_{2} \mathrm{O}_{2}$. The following section details various catalysts used in Li-air batteries.

\subsection{Metal Oxide}

The mechanism of metal oxides catalyzed electrochemical reaction in Li-air battery remains unclear. Nevertheless, research shows metal oxides can accelerate oxidation of lithium metal. These metal oxides may also accelerate the electrochemical reaction in ORR and assist decomposition of lithium oxide in OER.
Manganese oxide $\left(\mathrm{MnO}_{2}\right)$ is one of the frequently used metal oxides for Li-air batteries. $\alpha-\mathrm{MnO}_{2}$ has a high discharge voltage plateau of 2.7-2.9 $\mathrm{V}$ with fair capacity of $545 \mathrm{mAh} \mathrm{g}_{\text {catalyst }}{ }^{-1}$ at a current density of $0.025 \mathrm{~mA} / \mathrm{cm}^{2}$ [40]. The superior performance of $\alpha$ $\mathrm{MnO}_{2}$ is mainly due to the bifunctional catalytic activities of $\alpha$-manganese oxide which lead to high decomposition rate constant $\left(0.53 \pm 0.03 \mathrm{~s}^{-1} \mathrm{~g}^{-1}\right)$ [41].

Various modifications have been attempted on $\mathrm{MnO}_{2}$ to further improve its electrochemical performance. For example, Cao and his coworkers grew $\alpha-\mathrm{MnO}_{2}$ nanorods in situ on graphene as catalysts for Li-air batteries [42]. The $\mathrm{a}-\mathrm{MnO}_{2} / \mathrm{GN}$ hybrid demonstrated an exceptional high reversible specific capacity of $11520 \mathrm{mAh} \mathrm{g}_{\text {carbon }}{ }^{-1}$ at a current density of $200 \mathrm{~mA} \mathrm{~g}_{\text {carbon }}{ }^{-1}$. It also reduced the voltage gap between charging and discharging to $1.0 \mathrm{~V}$. A relatively good capacity retention was demonstrated when the discharge depth was controlled at 2900 $\mathrm{mAh} / \mathrm{g}$. The hybrid exhibited considerably low charge voltage for the OER process at about $3.85 \mathrm{~V}$, which is comparable to that of catalysts based on noble metals (Figure 8). The superior performance of the hybrid was attributed to presence of larger pore volume on the hybrid catalyst [42].

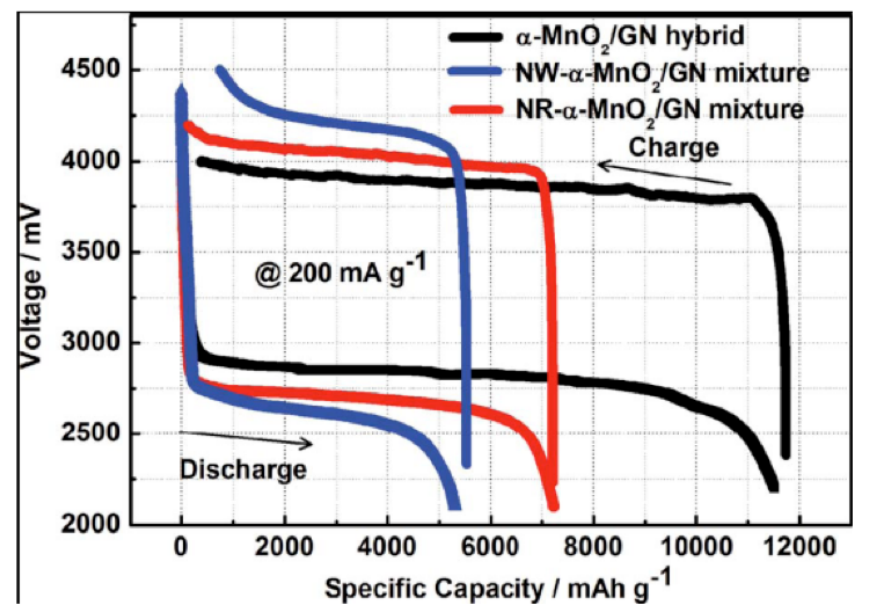

Figure 8: Charge and discharge curves of Li-air batteries based on different catalysts. The hybrid perform much better than these two kinds of mixture. Reprinted from ref. [39].

Carbon-supported manganese oxide $\left(\mathrm{MnO}_{2}\right)$ is another type of modified manganese oxide used as a catalyst for Li-air batteries [43]. It is synthesized by uniformly distributing $\mathrm{MnO}_{2}$ nanoparticles (20-50 nm) on carbon matrix (Figure 9). Cathodes containing these $\mathrm{MnO}_{2}$ nanoparticles were assembled into a Swagelok cell with $1 \mathrm{M} \mathrm{LiPF}_{6}$ in propylene carbonate electrolyte. The discharge capacity was about $4150 \mathrm{mAh} \mathrm{g}_{\text {carbon }}{ }^{-1}$ with the discharge potential of 2.5 $-2.7 \mathrm{~V}$ (Figure 10). 
This nanocatalyst has higher electrochemical performance in comparison to electrolytic manganese dioxide (EMD) which can be further enhanced by thermal treatment.

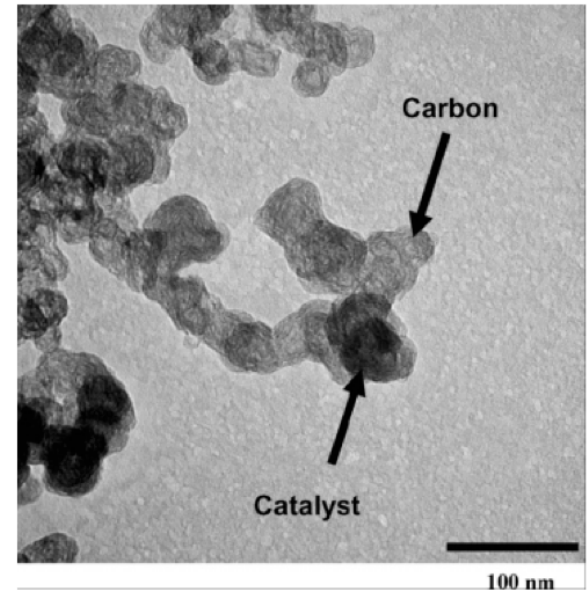

Figure 9: TEM image of the Norit carbon-supported manganese oxide. $\mathrm{MnO}_{2}$ nanoparticles are uniformly dispersed on carbon substrate. Reprinted from ref. [40].

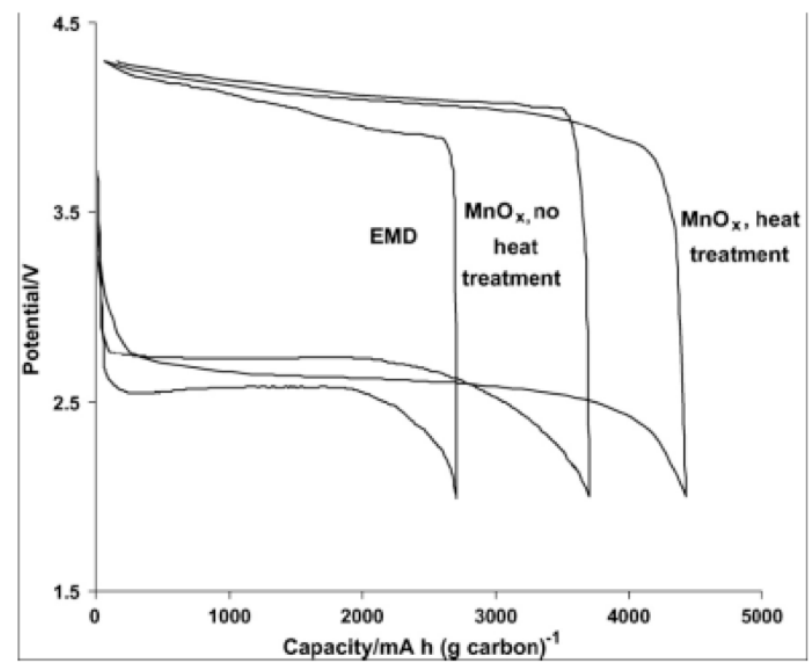

Figure 10: Voltage-capacity curves of the first cycle of Li-air batteries using $\mathrm{EMD}, \mathrm{MnO}_{\mathrm{x}}$ with or without heat treatment at a current density of $200 \mathrm{~mA}_{\text {gcarbon }}{ }^{-1}$. Reprinted from ref. [40].

Li et al. coated $\mathrm{MnO}_{2}$ nanoflakes onto multi-walled carbon nanotubes (MWNTs) as catalyst for an optimized air cathode [44]. This battery delivers a large capacity of $1768 \mathrm{mAh} / \mathrm{g}_{\text {carbon }}$ at a current density of 70 $\mathrm{mA} / \mathrm{g}_{\text {carbon }}$ in $\mathrm{O}_{2}$, while the charge voltage potential was 3.8 $\mathrm{V}$ [45]. This phenomenon may be attributed to the chemical bonds between MWNTs and $\mathrm{MnO}_{2}$.

To increase and stabilize the porosity of air cathode, Ida et al. prepared manganese oxides with card-houselike structure [46]. The molar ratio $\left(\mathrm{e}^{-} / \mathrm{O}_{2}\right)$ in the discharge reaction was approximately 2 , which means almost only $\mathrm{Li}_{2} \mathrm{O}_{2}$ was produced. This in turn indicates that Manganese oxide with this kind of structure has a higher catalytic activity than that of EMD.

Lee et al. synthesized $\mathrm{Na}_{0.44} \mathrm{MnO}_{2}$ nanowire with a tunnel-type crystal structure by a hydrothermal method and used it as air cathode [47]. An excellent specific capacity of $\sim 5700 \mathrm{mAh} / \mathrm{g}$ can be reached in $1.0 \mathrm{M}$ $\mathrm{LiPF}_{6}$ in tetraethylene glycol dimethoxyethane (TEGDME). To further improve the performance, they treated the pristine samples with nitric acid to prepare acid-leached $\mathrm{Na}_{0.44} \mathrm{MnO}_{2}$ nanowires to induce more structural defects. An extraordinary specific capacity of $\sim 11000 \mathrm{mAh} / \mathrm{g}$ at a rate of $70 \mathrm{~mA} / \mathrm{g}$ of carbon was reached in the first cycle, almost double than that of the pristine $\mathrm{Na}_{0.44} \mathrm{MnO}_{2}(\sim 5700 \mathrm{mAh} / \mathrm{g})$. Both pristine and the acid-leached $\mathrm{Na}_{0.44} \mathrm{MnO}_{2}$ show much better performance than $\alpha-\mathrm{MnO}_{2}(2300 \mathrm{mAh} / \mathrm{g})$.

In addition to $\mathrm{MnO}_{2}, \mathrm{Co}_{3} \mathrm{O}_{4}$ is another typical type of metal oxide. Cui et al. designed a free-standing-type air cathode by growing $\mathrm{Co}_{3} \mathrm{O}_{4}$ nanorods on $\mathrm{Ni}$ foam [48]. It has a discharge and charge voltage of $2.95 \mathrm{~V}$ and 3.44 $\mathrm{V}$, respectively at a specific capacity of $4000 \mathrm{mAh} / \mathrm{g}$ (the mass of the cathode includes carbon, binder and catalyst). This extraordinary performance is due to the bifunctional catalytic activities of $\mathrm{Co}_{3} \mathrm{O}_{4}[49]$.

Liang and his coworkers loaded $\mathrm{Co}_{3} \mathrm{O}_{4}$ nanocrystals onto graphene nanosheets by a modified Hummers method [50]. They found that these $\mathrm{Co}_{3} \mathrm{O}_{4}$ and graphene hybrids, especially $\mathrm{Co}_{3} \mathrm{O}_{4} / \mathrm{N}-\mathrm{rmGO}$, exhibited surprisingly high ORR activities which is comparable to that of fresh commercial $\mathrm{Pt} / \mathrm{C}$. Oxygen reduction polarization curves shows 10,000-25,000s of continuous operation with little decay. It also demonstrated higher stability and durability.

In short, metal oxide can sustain constantly altering current during charging and discharging process. Batteries using these catalysts have excellent recyclabilities.

\subsection{Noble Metal Catalyst}

Although not as stable as metal oxide, pure metals have higher conductivity and cells utilize them as catalysts have outstanding cyclability. Noble metals are resistant to corrosion and oxidation in moist air. Ruthenium, rhodium, palladium, silver, osmium, iridium, platinum, and gold are common noble metals. They are widely used as catalysts in cathodes for fuel cells in the past decades [51]. Nowadays, their application has been widened to include catalysts for Li-air batteries. 
$\mathrm{Lu}$ et al. synthesized PtAu bifunctional electrocatalyst to reduce voltage gap and achieve high round-trip efficiency [52]. The $\mathrm{Pt}$ element in PtAu bifunctional electrocatalyst significantly decreases OER potential; meanwhile Au element in PtAu bifunctional electrocatalyst increases ORR potential [53, 54, 55]. The high ORR catalytic performance and low OER catalytic performance of noble metal catalysts such as $\mathrm{Pt}$ and Au nanoparticles are probably due to the strong anti-bonding $\sigma^{*}\left(2 p_{z}\right)$ level of metal substrate in the $\mathrm{Li}_{2} \mathrm{O}_{2}$ conduction and low coupling level of metal substrate in the $\mathrm{Li}_{2} \mathrm{O}_{2}$ bulk states [56].

Yang et al. used platinum nanoparticle-loaded graphene hybrids as cathode catalysts for Li-air batteries [57]. Compared with free-standing graphenen nanosheetsthe PtNP-GNS showed a decreased voltage gap and an increased specific capacity.

In addition to the noble metal catalyst, electrolyte solvent decomposition causes a major problem in electrochemical reaction. McCloskey and his coworkers compared the catalytic activities of four different materials namely Vulcan XC72, $40 \mathrm{wt} \% \mathrm{Au} / \mathrm{XC72}$ and $40 \mathrm{wt} \% \mathrm{Pt} / \mathrm{XC} 72$ anda- $\mathrm{MnO}_{2}$ nanowires in 1PC:1DME [58]. Figure 11a shows $\mathrm{Pt} / \mathrm{XC72}$ has excellent voltage gap reduction. Nevertheless, Figure $11 \mathrm{~b}$ and $11 \mathrm{c}$ depicts high amount of $\mathrm{CO}_{2}$ was evolved and low amount of $\mathrm{O}_{2}$ during the charge-discharge procedure which indicated $\mathrm{Li}_{2} \mathrm{O}_{2}$ decomposition. Thus, the voltage gap reduction was not due to the improvement of ORR. Instead, it was due to the decomposition of electrolyte solvent. When electrolyte solvent 1DME was used instead of $1 \mathrm{PC}: 1 \mathrm{DME}$, only $\mathrm{Pt} / \mathrm{XC} 72$ showed voltage gap reduction property (Figure 12). Thus, "superior" performance of $\mathrm{Pt} / \mathrm{XC72}$ is probably due to its ability to catalyze decomposition of DME, which must be alleviated as much as possible.

Cheng et al. compared the catalytic performance of metals ( $\mathrm{Pt}, \mathrm{Pd}$ and $\mathrm{Ru}$ ) and their oxides [59]. They concluded that metal oxide catalysts have better stability and underwent a smaller surface change; thus, better capacity retention.

Pt nanoparticles also were loaded onto mesoporous carbon nitride (MCN) as a bifunctional air electrode for a solid-state lithium air cell [60]. The Pt@MCN electrode delivered high round-trip efficiency up to $87 \%$ with a high discharge voltage at around $2.87 \mathrm{~V}$ and a very low charge voltage at about $3.30 \mathrm{~V}$. When the carbon substrate was changed to acetylene black (AB), the Pt@AB showed a similar OER voltage indicating Pt nanoparticles are responsible for the OER kinetics.

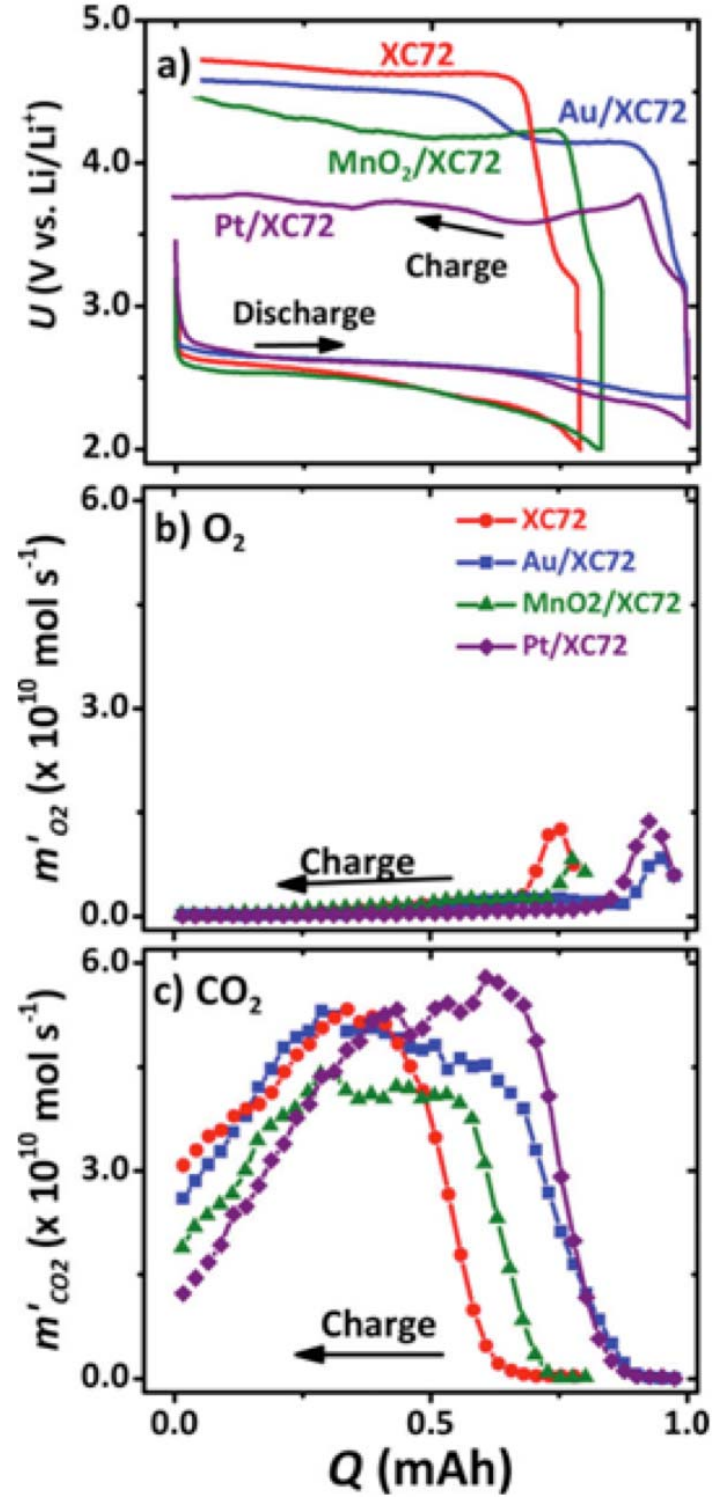

Figure 11: (Left) Gas evolution fromcells employing 1PC:1DME. (a) Discharge-charge voltage curves, and corresponding $\mathrm{O} 2$ (b) and $\mathrm{CO} 2$ (c) evolutionduring charging of cells using various cathode catalysts. Reprinted from ref. [55].

\subsection{Multi-Metal Oxide}

Trahey et al. implemented lithium-metal oxides with a high formal $\mathrm{Li}_{2} \mathrm{O}$ content [61], such as $\mathrm{Li}_{5} \mathrm{FeO}_{4}$ $\left(5 \mathrm{Li}_{2} \mathrm{O} \cdot \mathrm{Fe}_{2} \mathrm{O}_{3}\right)$ and a $\mathrm{Li}_{2} \mathrm{MnO}_{3} \cdot \mathrm{LiFeO}_{2}$ composite ( $<\mathrm{Li}_{2} \mathrm{O} \cdot \mathrm{MnO}_{2}><\mathrm{Li}_{2} \mathrm{O} \cdot \mathrm{Fe}_{2} \mathrm{O}_{3}$ ) ) as electrochemical catalysts for air cathode, because they thought the $\mathrm{Li}_{2} \mathrm{O}$ extraction process will favor an outstanding performance of $\mathrm{Li}$-air cells. $\mathrm{Li}_{5} \mathrm{FeO}_{4}$ shows a much better electrochemical activity after the first charge. Acid treated $\mathrm{Li}_{2} \mathrm{MnO}_{3} \cdot \mathrm{LiFeO}_{2}$ also demonstrates a better electrochemical performance than that of the pristine one. This proved that these materials can be activated after $\mathrm{Li}_{2} \mathrm{O}$ removed. From all these results, 
they believed that they are extending a promising approach to ensure the reversibility of lithium air batteries from the extraction and accommodation of $\mathrm{Li}_{2} \mathrm{O}$ with the catalysts.

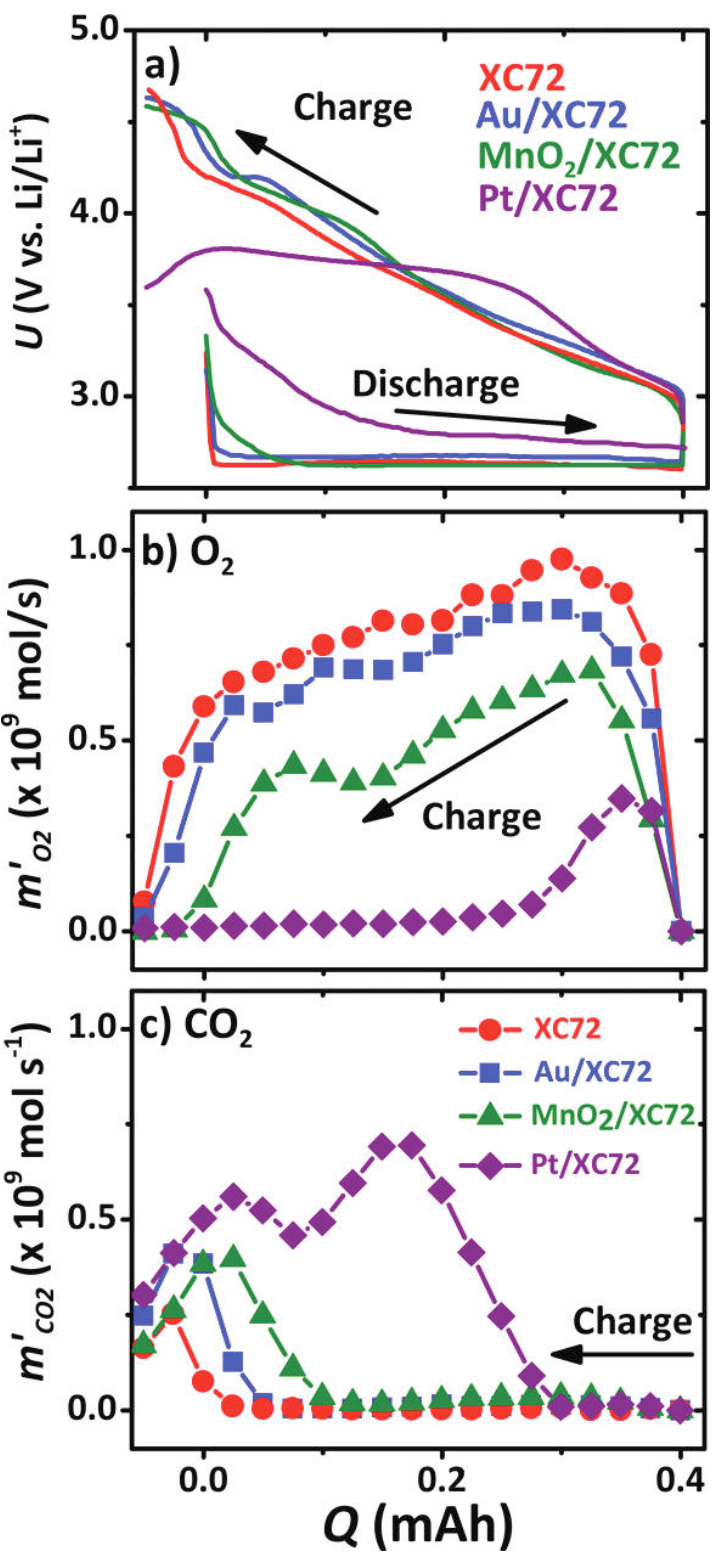

Figure 12: (Right) Gas evolution from cells employing DME. (a) Discharge- charge voltage curves, and corresponding $\mathrm{O}_{2}$ (b) and $\mathrm{CO}_{2}$ (c) evolution during charging of cells based on diverse cathode catalysts. Reprinted from ref. [55].

Multi-metal oxides containing $\mathrm{Co}$ and $\mathrm{Mn}$ elements have bifunctional catalytic activity. Wang et al. grew $\mathrm{CoMn}_{2} \mathrm{O}_{4}$ spinel Nanoparticles on graphene as catalyst [62]. RDE measurement confirmed the bifunctional catalytic activity of the material.

$\mathrm{MnCo}_{2} \mathrm{O}_{4}$-graphene hybrid can also be utilized in air electrode [63]. The cells demonstrated a specific capacity of $3784 \mathrm{mAh} / \mathrm{g}$ based on the total mass of the $\mathrm{MnCo}_{2} \mathrm{O}_{4}$-graphene hybrid at a current density of 100
$\mathrm{mA} / \mathrm{g}$. Besides this, the cell showed an average discharging voltage of about $2.95 \mathrm{~V}$ and an average charge voltage of $3.75 \mathrm{~V}$ in pure oxygen, which means the voltage gap is only $0.8 \mathrm{~V}$. These results proved a covalently coupled $\mathrm{MnCo}_{2} \mathrm{O}_{4}$-graphene hybrid material is an active, stable and low-cost cathode catalyst for $\mathrm{Li}-\mathrm{O}_{2}$ batteries.

Zhang and his coworkers utilized hollandite $\mathrm{Ag}_{2} \mathrm{Mn}_{8} \mathrm{O}_{16}$ as catalyst for Li-air batteries [64]. The catalyst was prepared by solid-state chemical method. Li-cell with $\mathrm{Ag}_{2} \mathrm{Mn}_{8} \mathrm{O}_{16}$ catalyst had a higher specific capacity and discharge voltage platform than that without catalyst (Figure 13).

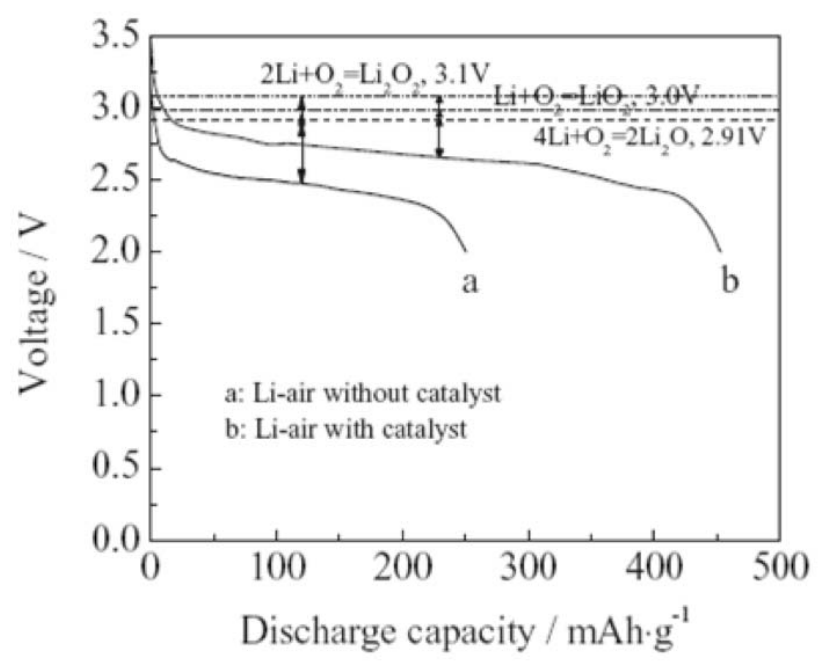

Figure 13: Discharge curves of Li-air cells with or without the catalyst $\mathrm{Ag}_{2} \mathrm{Mn}_{8} \mathrm{O}_{16}$ at a current density of $0.2 \mathrm{~mA} / \mathrm{cm}^{-2}$. The curves proved catalytic activity of this product. Reprinted from ref. [61].

\subsection{Metal Organic Compounds and Metal Nitrides}

Metal nitrides and metal organic compounds are also used as catalyst in Li-air batteries. Zhang et al. used FeCu-phthalocyanine (FeCuPc) complexes as the catalyst [65]. In this experiment, they adopt a special electrolyte using 7:3 (wt.) propylene carbonate (PC)/tris(2,2,2-trifluoroethyl) phosphate (TFP) as solvent, which proved to be superior to other carbonate-based electrolytes [66, 67]. The $\mathrm{FeCu} / \mathrm{C}$ material was then prepared by absorbing FeCuPc complex onto Ketjenblack EC-600JD carbon black and subsequently heated. $\mathrm{FeCu} / \mathrm{C}$ also demonstrated a lower impedance and lower current in comparison with control cell with pristine carbon. Considering the fact that metal oxide will form at a high temperature, they concluded that the $0.3 \mathrm{~V}$ higher open-circuit voltage was due to the catalyst itself. In the consecutive discharge test, the $\mathrm{FeCu} / \mathrm{C}$ cell shows about $0.2 \mathrm{~V}$ higher 


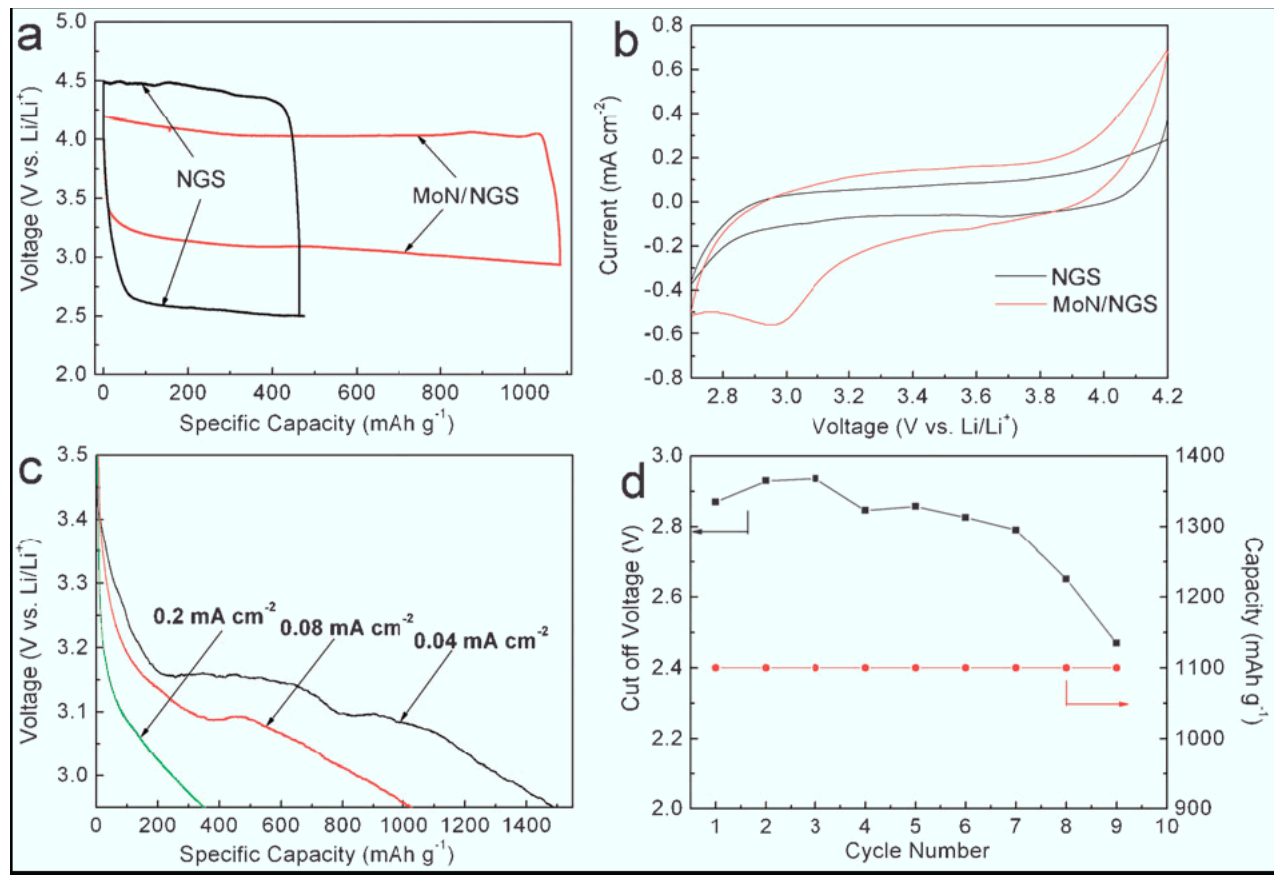

Figure 14: (a) at the current density of $0.08 \mathrm{~mA} \mathrm{~cm}^{-2} ;(\mathbf{b}) \mathrm{CV}$ curves at a scan rate of $1 \mathrm{mV} \mathrm{s}^{-1}$; (c) discharge curves of MoN/NGS at different current densities; (d) cycle performance of MoN/NGS cathode based Li-air batteries with capacity restriction at a current density of $0.08 \mathrm{~mA} \mathrm{~cm}^{-2}$ (red) and the resulting cutoff voltage of discharge (black). Reprinted from ref. [65].

discharge voltage than the control cell. But if we do not take the capacity of the second voltage plateau of 1.7 $\mathrm{V}$, which is due to the catalyst-induced solvent decomposition [68], into account, the specific capacity of the $\mathrm{FeCu} / \mathrm{C}$ cell is a little lower than that of pristine carbon cell. Similar results could also be obtained from intermittent discharge. They subsequently designed an experiment to prove that the $\mathrm{FeCu} / \mathrm{C}$ not only accelerates the formation of $\mathrm{Li}_{2} \mathrm{O}_{2}$, but also catalyzes the non-redox $\mathrm{Li}_{2} \mathrm{O}_{2}$ disproportionation, although its activity on this reaction not so effective as its activity on the formation of $\mathrm{Li}_{2} \mathrm{O}_{2}$.

Dong et al. utilized molybdenum nitride as catalyst [69]. MoN/NGS were synthesized through a hydrothermal reaction followed by ammonia annealing. SEM and TEM images showed that MoN nanoparticles was dispersed homogeneously on the thin layer of GNS. As depicted in Figure 14, the specific capacity of $1000 \mathrm{mAh} / \mathrm{g}$ at a current density of $0.08 \mathrm{~mA} \mathrm{~cm}^{-2} \mathrm{did}$ not seem a high capacity, but voltage plateau between 3.2 and $3.0 \mathrm{~V}$ was even higher than that of PtAu/C (around 2.8V) [52].

Zhang et al. prepared a multi-metal nitride $\mathrm{Co}_{3} \mathrm{Mo}_{3} \mathrm{~N}$ as catalyst by nitriding a cobalt molybdate hydrate $\left(\mathrm{CoMoO}_{4}\right)$ precursor [70]. As depicted in Figure 15, the catalyst could not dramatically enhance the initial specific capacity. However, it displayed excellent bifunctional electrocatalytic activity for ORR/OER.
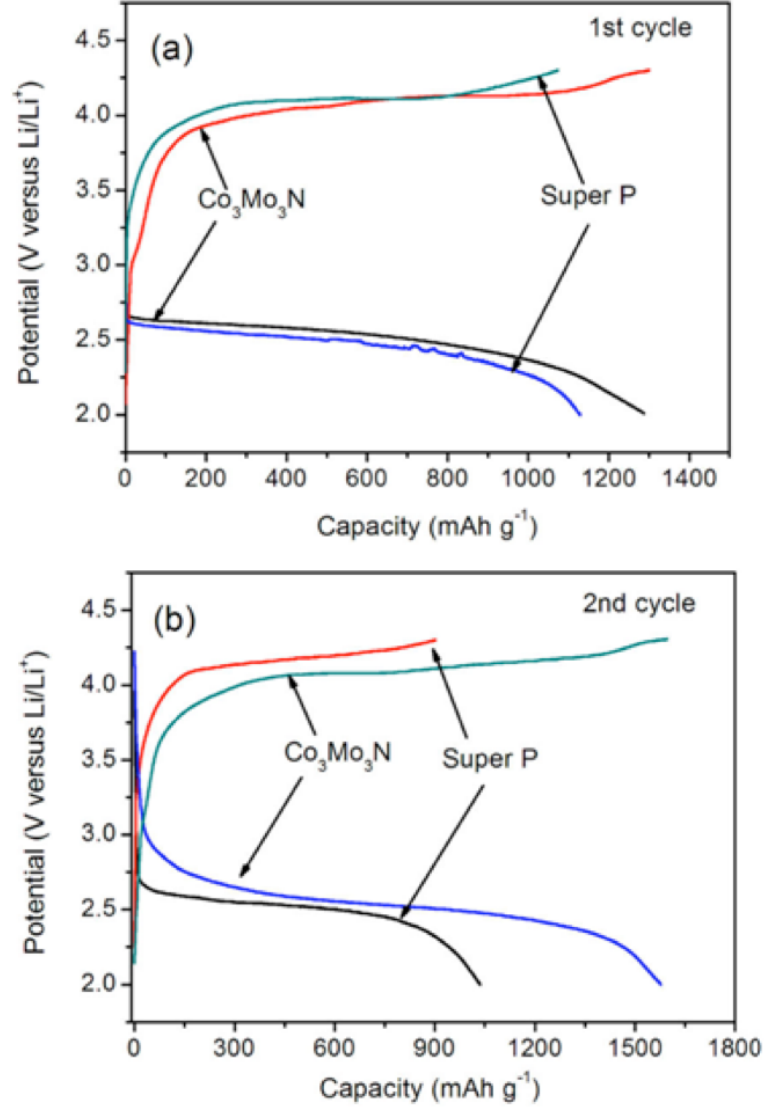

Figure 15: Li-air cell discharge/charge profiles of super $\mathrm{P}$ and $\mathrm{Co}_{3} \mathrm{Mo}_{3} \mathrm{~N}$-based electrode at the current density of $0.1 \mathrm{~mA}$ $\mathrm{cm}^{-2}$ for (a) the first cycle and (b) the second cycle. From these discharge curves, the catalyst showed an apparent bifunctional catalytic activity with a decreased voltage gap Reprinted from ref. [66]. 
Preparing mesoporous oxides without using hard scaffolds is an important progress [71]. Si Hyoung Oh and his coworkers implemented a metallic mesoporous pyrochlore as a catalyst for air cathode [72]. The cell using mesoporous pyrochlores as catalyst exhibited high reversible capacity of $10000 \mathrm{mAh} / \mathrm{g}$ (electrode weight including the discharge product) by the third cycle at a current density of $70 \mathrm{~mA} / \mathrm{g}$ of carbon.

\section{CONCLUSIONS AND PERSPECTIVES}

The use of porous carbon-based materials as air cathode substrate helps the diffusion of oxygen. Pores on micrometer length scales acts as "highway" for oxygen transport. Catalysts loaded onto porous carbon materials increases the rate of OER and ORR and maintains a balance between oxygen diffusion and the two reactions to enhance the performance of the batteries. They also decrease the voltage gap between two reactions to achieve high round-trip efficiency.

Air cathode of Li-air batteries should have carbon material with proper pores diameter in order to have sufficient air diffusion. It should also contain catalysts with suitable nanostructures to enhance electrical transport. As pores of air cathode are always blocked by discharge products which severely affect the cyclability of Li-air batteries, it will be crucial to control the deposition of the discharge products to ensure highways for air diffusion will not be blocked. In addition, the mechanism of electrocatalysis is still poorly understood. Thus, it will be difficult to design suitable nanostructures for the catalysts. Finally, it is also necessary to design a mechanism to prevent $\mathrm{CO}_{2}$ and $\mathrm{H}_{2} \mathrm{O}$ invasion on air cathode as this will severely deteriorate the performance of air cathode.

\section{ACKNOWLEDGEMENTS}

Zha thanks Liu Yang for helpful discussions. We thank the National Natural Science Foundation of China (Grant No. 51371186 and 21303236), the recruitment program of global experts of Central Organization Department, the Project of the Ningbo 3315 International Team, and NIMTE, CAS (Y20838RA23, Y30805WA06 and Y30806RA05).

\section{REFERENCES}

[1] Girishkumar G, McCloskey B, Luntz AC, S. Swanson aWW. Lithium-Air Battery: Promise and Challenges. J Phys Chem Lett 2010; 1: 2193-203. http://dx.doi.org/10.1021/jz1005384

[2] Takeshi Ogasawara, Aurélie Débart, Michael Holzapfel, Petr Nova' k aPGB. Rechargeable Li2O2 electrode for lithium batterirs. J Am Chem Soc 2006; 128: 1390-3. http://dx.doi.org/10.1021/ja056811d
[3] Hun-Gi Jung JH, Park J-B, Sun Y-K, Scrosati B. An improved high-performance lithium-air battery. Nat Chem 2012; 4: 579-85.

http://dx.doi.org/10.1038/nchem.1376

[4] He P, Wang Y, Zhou H. A Li-air fuel cell with recycle aqueous electrolyte for improved stability. Electrochem Commun 2010; 12(12): 1686-9. http://dx.doi.org/10.1016/j.elecom.2010.09.025

[5] Kumar B, Kumar J, Leese R, Fellner JP, Rodrigues SJ, Abraham KM. A Solid-State, Rechargeable, Long Cycle Life Lithium-Air Battery. J Electrochem Soc 2010; 157(1): A50. http://dx.doi.org/10.1149/1.3256129

[6] Wang $\mathrm{Y}$, Zhou H. A lithium-air battery with a potential to continuously reduce $\mathrm{O} 2$ from air for delivering energy. $\mathrm{J}$ Power Sources 2010; 195(1): 358-61. http://dx.doi.org/10.1016/i.jpowsour.2009.06.109

[7] Zhang $T$, Imanishi N, Shimonishi $\mathrm{Y}$, Hirano A, Takeda $\mathrm{Y}$, Yamamoto $\mathrm{O}$, et al. A novel high energy density rechargeable lithium/air battery. Chem Commun 2010; 46(10): 1661.

http://dx.doi.org/10.1039/b920012f

[8] Zhang T, Imanishi N, Hasegawa S, Hirano A, Xie J, Takeda $\mathrm{Y}$, et al. Water-Stable Lithium Anode with the Three-Layer Construction for Aqueous Lithium-Air Secondary Batteries. Electrochem. Solid-State Lett 2009; 12(7): A132.

[9] Christensen J, Albertus P, Sanchez-Carrera RS, Lohmann T, Kozinsky B, Liedtke R, et al. A Critical Review of Li/Air Batteries. J Electrochem Soc 2012; 159(2): R1. http://dx.doi.org/10.1149/2.030301jes

[10] Kraytsberg A, Ein-Eli Y. Review on Li-air batteriesOpportunities, limitations and perspective. J Power Sources 2011; 196(3): 886-93. http://dx.doi.org/10.1016/i.jpowsour.2010.09.031

[11] Trahan MJ, Mukerjee S, Plichta EJ, Hendrickson MA, Abraham KM. Studies of Li-Air Cells Utilizing Dimethyl Sulfoxide-Based Electrolyte. J Electrochem Soc 2012; 160(2): A259-A67.

http://dx.doi.org/10.1149/2.048302jes

[12] Wang J, Li Y, Sun X. Challenges and opportunities of nanostructured materials for aprotic rechargeable lithium-air batteries. Nano Energy 2013; 2(4): 443-67. http://dx.doi.org/10.1016/j.nanoen.2012.11.014

[13] Hendrickson EJPaMA. Elucidating the Mechanism of Oxygen Reduction for Lithium-Air Battery Applications. J Phys Chem C 2009; 113(46): 20127-34. http://dx.doi.org/10.1021/jp908090s

[14] Lu Y-C, Gasteiger HA, Crumlin E, McGuire R, Shao-Horn Y. Electrocatalytic Activity Studies of Select Metal Surfaces and Implications in Li-Air Batteries. J Electrochem Soc 2010; 157(9): A1016 http://dx.doi.org/10.1149/1.3462981

[15] Kuboki T, Okuyama T, Ohsaki T, Takami N. Lithium-air batteries using hydrophobic room temperature ionic liquid electrolyte. J Power Sources 2005; 146(1-2): 766-9.

http://dx.doi.org/10.1016/j.jpowsour.2005.03.082

[16] Xiao J, Wang D, Xu W, Wang D, Williford RE, Liu J, et al. Optimization of Air Electrode for Li/Air Batteries. J Electrochem Soc 2010; 157(4): A487. http://dx.doi.org/10.1149/1.3314375

[17] Zhang SS, Foster D, Read J. Discharge characteristic of a non-aqueous electrolyte Li/O2 battery. J Electrochem Soc 2010; 195(4): 1235-40.

[18] Xiao J, Mei D, Li X, Xu W, Wang D, Graff GL, et al. Hierarchically Porous Graphene as a Lithium-Air Battery Electrode Nano Lett 2011; 11(11): 5071-8. http://dx.doi.org/10.1021/nl203332e

[19] Freunberger SA, Chen Y, Drewett NE, Hardwick LJ, Bardé F, Bruce PG. The Lithium-Oxygen Battery with Ether-Based Electrolytes. Angew Chem Int Ed 2011; 50(37): 8609-13. http://dx.doi.org/10.1002/anie.201102357 
[20] Beattie SD, Manolescu DM, Blair SL. High-Capacity LithiumAir Cathodes. J Electrochem Soc 2009; 156(1): A44. http://dx.doi.org/10.1149/1.3005989

[21] Ayala $P$, Arenal $R$, Rümmeli M, Rubio A, Pichler T. The doping of carbon nanotubes with nitrogen and their potential applications. Carbon 2010; 48(3): 575-86. http://dx.doi.org/10.1016/j.carbon.2009.10.009

[22] Xingbang $\mathrm{Hu} \mathrm{YW}$, Li H, Zhang Z. Adsorption and Activation of $\mathrm{O} 2$ on Nitrogen-Doped Carbon Nanotubes. J Phys Chem C 2010; 114: 9603-7.

\section{http://dx.doi.org/10.1021/jp1000013}

[23] Shan B, Cho K. Oxygen dissociation on nitrogen-doped single wall nanotube: A first-principles study. Chem Phys Lett 2010; 492(1-3): 131-6.

http://dx.doi.org/10.1016/i.cplett.2010.04.050

[24] Kichambare P, Kumar J, Rodrigues S, Kumar B. Electrochemical performance of highly mesoporous nitrogen doped carbon cathode in lithium-oxygen batteries. J Power Sources 2011; 196(6): 3310-6.

http://dx.doi.org/10.1016/j.jpowsour.2010.11.112

[25] Yongliang Li XL, Geng D, Tang Y, Li R, Dodelet J-P, Lefèvre $M$, Sun $X$. Carbon black cathodes for lithium oxygen batteries: Influence of porosity and heteroatom-doping. Carbon 2013; 64: 170-7.

http://dx.doi.org/10.1016/j.carbon.2013.07.049

[26] Stevenson JDW-CaKJ. Effect of Nitrogen Concentration on Capacitance, Density of States, Electronic Conductivity. J Phys Chem C 2009; 113: 19082-90.

http://dx.doi.org/10.1021/jp907160v

[27] Li Y, Wang J, Li X, Liu J, Geng D, Yang J, et al. Nitrogendoped carbon nanotubes as cathode for lithium-air batteries. Electrochem Commun 2011; 13(7): 668-72. http://dx.doi.org/10.1016/j.elecom.2011.04.004

[28] Zhang GQ, Zheng JP, Liang R, Zhang C, Wang B, Hendrickson $\mathrm{M}$, et al. Lithium-Air Batteries Using SWNT/CNF Buckypapers as Air Electrodes. J Electrochem Soc 2010; 157(8): A953.

http://dx.doi.org/10.1149/1.3446852

[29] Mitchell RR, Gallant BM, Thompson CV, Shao-Horn Y. Allcarbon-nanofiber electrodes for high-energy rechargeable Li-O2 batteries. Energy Environ Sci 2011; 4(8): 2952.

http://dx.doi.org/10.1039/c1ee01496j

[30] Yang X-H, He P, Xia Y-Y. Preparation of mesocellular carbon foam and its application for lithium/oxygen battery. Electrochem Commun 2009; 11(6): 1127-30. http://dx.doi.org/10.1016/j.elecom.2009.03.029

[31] Novoselov KS, Fal'ko VI, Colombo L, Gellert PR, Schwab MG, Kim K. A roadmap for graphene. Nature 2012; 490(7419): 192-200.

http://dx.doi.org/10.1038/nature11458

[32] Zhu Y, Murali S, Stoller MD, Ganesh KJ, Cai W, Ferreira PJ, et al. Carbon-Based Supercapacitors Produced by Activation of Graphene. Science 2011; 332(6037): 1537-41.

http://dx.doi.org/10.1126/science.1200770

[33] Sun B, Wang B, Su D, Xiao L, Ahn H, Wang G. Graphene nanosheets as cathode catalysts for lithium-air batteries with an enhanced electrochemical performance. Carbon 2012; 50(2): 727-33.

http://dx.doi.org/10.1016/j.carbon.2011.09.040

[34] Yoo E, Nakamura J, Zhou H. N-Doped graphene nanosheets for Li-air fuel cells under acidic conditions. Energy Environ Sci 2012; 5(5): 6928.

http://dx.doi.org/10.1039/c2ee02830a

[35] Yongliang Li JW, Li X, Geng D, Banis MN, Li R, Sun X. Nitrogen-doped graphene nanosheets as cathode materials with excellent. Electrochem Commun 2012; 18(12-15).

[36] Schniepp HC, Li J-L, McAllister MJ, Sai H. Functionalized Single Graphene Sheets Derived from Splitting Graphite Oxide. J Phys Chem B 2006; 110(17): 8535-9.

http://dx.doi.org/10.1021/jp060936f
[37] Wang Z-L, Xu D, Xu J-J, Zhang L-L, Zhang X-B. Graphene Oxide Gel-Derived, Free-Standing, Hierarchically Porous Carbon for High-Capacity and High-Rate Rechargeable LiO2 Batteries. Adv Funct Mater 2012; 22(17): 3699-705.

http://dx.doi.org/10.1002/adfm.201200403

[38] Wang Y, Cao D, Wang G, Wang S, Wen J, Yin J. Spherical clusters of $\beta-\mathrm{Ni}(\mathrm{OH}) 2$ nanosheets supported on nickel foam for nickel metal hydride battery. Electrochim Acta 2011; 56(24): 8285-90.

http://dx.doi.org/10.1016/j.electacta.2011.06.098

[39] Marcus A. Worsley PJP, Tammy Y. Olson, Juergen Biener, Joe H. Satcher, Jr., Baumann aTF. Synthesis of Graphene Aerogel with High Electrical Conductivity. J Am Chem Soc 2010; 132: 14067-9. http://dx.doi.org/10.1021/ja1072299

[40] Thapa AK, Hidaka Y, Hagiwara H, Ida S, Ishihara T. Mesoporous $\beta-\mathrm{MnO} 2$ Air Electrode Modified with $\mathrm{Pd}$ for Rechargeability in Lithium-Air Battery. J Electrochem Soc 2011; 158(12): A1483. http://dx.doi.org/10.1149/2.090112jes

[41] Benbow EM, Kelly SP, Zhao L, Reutenauer JW, Suib SL. Oxygen Reduction Properties of Bifunctional a-Manganese Oxide Electrocatalysts in Aqueous and Organic Electrolytes. J Phys Chem C 2011; 115(44): 22009-17. http://dx.doi.org/10.1021/jp2055443

[42] Cao Y, Wei Z, He J, Zang J, Zhang Q, Zheng M, et al. a$\mathrm{MnO} 2$ nanorods grown in situ on graphene as catalysts for $\mathrm{Li}-\mathrm{O} 2$ batteries with excellent electrochemical performance. Energy Environ Sci 2012; 5(12): 9765. http://dx.doi.org/10.1039/c2ee23475k

[43] Cheng H, Scott K. Carbon-supported manganese oxide nanocatalysts for rechargeable lithium-air batteries. J Power Sources 2010; 195(5): 1370-4. http://dx.doi.org/10.1016/i.jpowsour.2009.09.030

[44] Li J, Wang N, Zhao Y, Ding Y, Guan L. MnO2 nanoflakes coated on multi-walled carbon nanotubes for rechargeable lithium-air batteries. Electrochem Commun 2011; 13(7): 698700.

http://dx.doi.org/10.1016/j.elecom.2011.04.013

[45] Débart A, Paterson AJ, Bao J, Bruce PG. a-MnO2 Nanowires: A Catalyst for the $\mathrm{O} 2$ Electrode in Rechargeable Lithium Batteries. Angew Chem 2008; 120(24): 4597-600. http://dx.doi.org/10.1002/ange.200705648

[46] Ida S, Thapa AK, Hidaka Y, Okamoto Y, Matsuka M, Hagiwara $\mathrm{H}$, et al. Manganese oxide with a card-house-like structure reassembled from nanosheets for rechargeable $\mathrm{Li}$ air battery. J Power Sources 2012; 203: 159-64. http://dx.doi.org/10.1016/j.jpowsour.2011.11.042

[47] Lee J-H, Black R, Popov G, Pomerantseva E, Nan F, Botton $\mathrm{GA}$, et al. The role of vacancies and defects in $\mathrm{Na0.44MnO2}$ nanowire catalysts for lithium-oxygen batteries. Energy Environ Sci 2012; 5(11): 9558. http://dx.doi.org/10.1039/c2ee21543h

[48] Cui Y, Wen Z, Liu Y. A free-standing-type design for cathodes of rechargeable $\mathrm{Li}-\mathrm{O} 2$ batteries. Energy Environ Sci $2011 ; 4(11): 4727$.

http://dx.doi.org/10.1039/c1ee02365a

[49] Black R, Lee J-H, Adams B, Mims CA, Nazar LF. The Role of Catalysts and Peroxide Oxidation in Lithium-Oxygen Batteries. Angew Chem Int Ed 2013; 52(1): 392-6. http://dx.doi.org/10.1002/anie.201205354

[50] Liang YY, Li YG, Wang HL, Zhou JG, Wang J, Regier T, et al. Co3O4 nanocrystals on graphene as a synergistic catalyst for oxygen reduction reaction. Nat Mater 2011; 10(10): 7806. http://dx.doi.org/10.1038/nmat3087

[51] Chan K-Y, Jie Ding JR, Tsang SCaKY. Supported mixed metal nanoparticles as electrocatalysts in low temperature fuel cells. J Mater Chem 2004; 14: 505-16.

http://dx.doi.org/10.1039/b314224h 
[52] Lu Y-C, Xu Z, Gasteiger HA, Chen S. Platinum-Gold Nanoparticles: A Highly Active Bifunctional Electrocatalyst for Rechargeable Lithium-Air Batteries. J Am Chen Soc 2010; 132: $12170-1$.

http://dx.doi.org/10.1021/ja1036572

[53] Lu Y-C, Gasteiger HA, Parent MC, Chiloyan V, Shao-Horn Y. The Influence of Catalysts on Discharge and Charge Voltages of Rechargeable Li-Oxygen Batteries. Electrochem. Solid-State Lett 2010; 13(6): A69. http://dx.doi.org/10.1149/1.3363047

[54] Lu Y-C, Gasteiger HA, Shao-Horn Y. Catalytic Activity Trends of Oxygen Reduction Reaction for Nonaqueous Li-Air Batteries. J Am Chem Soc 2011; 133(47): 19048-51. http://dx.doi.org/10.1021/ja208608s

[55] Lu Y-C, Kwabi DG, Yao KPC, Harding JR, Zhou J, Zuin L, et al. The discharge rate capability of rechargeable $\mathrm{Li}-\mathrm{O} 2$ batteries. Energy Environ Sci 2011; 4(8): 2999. http://dx.doi.org/10.1039/c1ee01500a

[56] Chen J, Hummelshøj JS, Thygesen KS, Myrdal JSG, Nørskov JK, Vegge T. The role of transition metal interfaces on the electronic transport in lithium-air batteries. Catal Today 2011; 165(1): 2-9. http://dx.doi.org/10.1016/j.cattod.2010.12.022

[57] Yang Y, Shi M, Zhou Q-F, Li Y-S, Fu Z-W. Platinum nanoparticle-graphene hybrids synthesized by liquid phase pulsed laser ablation as cathode catalysts for Li-air batteries. Electrochem Commun 2012; 20: 11-4. http://dx.doi.org/10.1016/j.elecom.2012.03.040

[58] McCloskey BD, Scheffler R, Speidel A, Bethune DS, Shelby RM, Luntz AC. On the Efficacy of Electrocatalysis in Nonaqueous Li-O2Batteries. J Am Chem Soc 2011; 133(45): 18038-41.

http://dx.doi.org/10.1021/ja207229n

[59] Cheng $\mathrm{H}$, Scott K. Selection of oxygen reduction catalysts for rechargeable lithium-air batteries-Metal or oxide? Appl Catal B Environ 2011; 108-109: 140-51. http://dx.doi.org/10.1016/j.apcatb.2011.08.021

[60] Lu Y, Wen Z, Jin J, Cui Y, Wu M, Sun S. Mesoporous carbon nitride loaded with $\mathrm{Pt}$ nanoparticles as a bifunctional air electrode for rechargeable lithium-air battery. J Solid State Electrochem 2012; 16(5): 1863-8. http://dx.doi.org/10.1007/s10008-012-1640-8

[61] Trahey L, Johnson CS, Vaughey JT, Kang SH, Hardwick LJ, Freunberger SA, et al. Activated Lithium-Metal-Oxides as Catalytic Electrodes for $\mathrm{Li}-\mathrm{O} 2$ Cells. Electrochem Solid-State Lett 2011; 14(5): A64. http://dx.doi.org/10.1149/1.3555366

[62] Wang L, Zhao X, Lu Y, Xu M, Zhang D, Ruoff RS, et al. CoMn2O4 Spinel Nanoparticles Grown on Graphene as
Bifunctional Catalyst for Lithium-Air Batteries. J Electrochem Soc $2011 ; 158(12)$ : A1379.

http://dx.doi.org/10.1149/2.068112jes

[63] Wang $\mathrm{H}$, Yang $\mathrm{Y}$, Liang $\mathrm{Y}$, Zheng G, Li $\mathrm{Y}$, Cui $\mathrm{Y}$, et al. Rechargeable $\mathrm{Li}-\mathrm{O} 2$ batteries with a covalently coupled MnCo2O4-graphene hybrid as an oxygen cathode catalyst. Energy Environ Sci 2012; 5(7): 7931.

http://dx.doi.org/10.1039/c2ee21746e

[64] Zhang GQ, Hendrickson M, Plichta EJ, Au M, Zheng JP. Preparation, Characterization and Electrochemical Catalytic Properties of Hollandite Ag2Mn8O16 for Li-Air Batteries. J Electrochem Soc 2012; 159(3): A310-A4. http://dx.doi.org/10.1149/2.085203jes

[65] Zhang SS, Ren X, Read J. Heat-treated metal phthalocyanine complex as an oxygen reduction catalyst for non-aqueous electrolyte Li/air batteries. Electrochim Acta 2011; 56(12): 4544-8. http://dx.doi.org/10.1016/j.electacta.2011.02.072

[66] Zhang SS, Read J. Partially fluorinated solvent as a cosolvent for the non-aqueous electrolyte of Li/air battery. $\mathrm{J}$ Power Sources 2011; 196(5): 2867-70.

http://dx.doi.org/10.1016/j.jpowsour.2010.11.021

[67] Zhang SS, Xu K, Read J. A non-aqueous electrolyte for the operation of Li/air battery in ambient environment. J Power Sources 2011; 196(8): 3906-10. http://dx.doi.org/10.1016/j.jpowsour.2010.12.092

[68] Ren X, Zhang SS, Tran DT, Read J. Oxygen reduction reaction catalyst on lithium/air battery discharge performance. J Mater Chem 2011; 21(27): 10118. http://dx.doi.org/10.1039/c0jm04170j

[69] Dong S, Chen X, Zhang K, Gu L, Zhang L, Zhou X, et al. Molybdenum nitride based hybrid cathode for rechargeable lithium-O2 batteries. Chem Commun 2011; 47(40): 11291. http://dx.doi.org/10.1039/c1cc14427h

[70] Zhang K, Zhang L, Chen X, He X, Wang X, Dong S, et al. Mesoporous Cobalt Molybdenum Nitride: A Highly Active Bifunctional Electrocatalyst and Its Application in LithiumO2Batteries. J Phys Chem C 2013; 117(2): 858-65. http://dx.doi.org/10.1021/jp310571y

[71] Cheng F, Chen J. Lithium-air batteries: Something from nothing. Nat Chem 2012; 4(12): 962-3. http://dx.doi.org/10.1038/nchem. 1516

[72] Si Hyoung Oh RB, Pomerantseva E, Lee J-H, Nazar LF. Synthesis of a metallic mesoporous pyrochlore as a catalyst for lithium-O2 batteries. Nat Chem 2012; 4: 1004-10. http://dx.doi.org/10.1038/nchem.1499 